\title{
Nicodemia madagascariensis (Lam.) R. Parker (Family Scrophulariaceae), a casual alien plant new to Italy
}

\author{
Salvatore Pasta ${ }^{\mathrm{a}}$, Emilio Badalamenti ${ }^{\mathrm{b}}$, Giovanna Sala ${ }^{\mathrm{b}}$ and Tommaso La Mantia ${ }^{\mathrm{b} *}$ \\ ${ }^{a}$ Consiglio Nazionale delle Ricerche, Istituto di Bioscienze e BioRisorse, Corso Calatafimi 414, Palermo, Italy; ${ }^{b}$ Dipartimento SAF, \\ Viale delle Scienze Ed. 4, Ingr. H, Palermo, Italy
}

(Received 24 September 2015; final version received 29 February 2016)

\begin{abstract}
In this note the authors report the first case of naturalization of the Malagasy smoke bush within Italian territory. Along with a description of the abiotic and biotic characteristics of the invaded site, the current demographic and dynamic trends of the detected population by means of growth-ring analysis was also assessed. Moreover, an overview on the history of its introduction in Europe is provided, underlining the key role played by the Mediterranean cities with respect to the acclimatization and spread of alien tropical and subtropical plants. Due to its low frequency under cultivation, the Malagasy smoke bush should not behave as an invader in the future; on the other hand, its ability to cover and smother neighbouring trees in very short times, make its spread within the whole Mediterranean area worth regular monitoring.
\end{abstract}

Keywords: growth rings; Mediterranean Basin; naturalization; reproductive traits

\section{Introduction}

Nicodemia madagascariensis (Lam.) R. Parker, known worldwide either with the basyonym Buddleja madagascariensis Lam. or the vernacular name Malagasy smoke bush, is an evergreen liana that has been introduced worldwide for ornamental purposes for its showy and abundant flowering.

Nicodemia madagascariensis is native to Madagascar, where it grows with other pioneer fast-growing shrubs in the inner highlands between 600 and $2000 \mathrm{~m}$ above sea level (Leeuwenberg 2005). Notwithstanding this ornamental plant has been introduced all over various continents and is considered as potentially invasive on a global scale, there is quite limited knowledge on its ecology within its native range. It is a common lightdemanding liana in managed forests and agro-forestry systems (Rakotondrasoa et al. 2012). Recent studies focused on the dynamic processes of local forest communities recovering from wildfires (Pareliussen 2004; Robisoa 2010) and highlighted its resilience and its outstanding frequency during the first stages of secondary succession, whereas it is outcompeted by the trees dominating the most mature stages. It also performs rapid resprouting through root suckers after mechanical damage by cutting and/or trampling (Stock and Wild 2002).

Frequently naturalized outside its native range, in many tropical and subtropical countries it is regarded as a major invader of natural habitats (Randall 2012). By contrast, naturalization cases in European countries have been hitherto quite limited.

Indeed, despite being cultivated in Europe for almost two centuries, the ability to escape from cultivation has been rarely observed, being restricted to southern Europe. Hence, our recent discovery of a spontaneous nucleus of this species in Sicily is of some relevance, because it represents the first naturalization case regarding the whole Italian territory.

\section{Material and methods}

Apart from providing detailed information about the geographical (GPS coordinates, altitude, area of occupation, etc.) and ecological (e.g. past and present land-use, co-occurring species, etc.) setting of the invaded site, and reporting the main characteristics of the alien population (number of individuals, estimated age, etc.), we aimed to retrace the history of its introduction in the Mediterranean area, Italy and Sicily. Lastly, we tried to forecast its ability to spread in the future.

Part of the research was addressed to understand the ecological role played by $N$. madagascariensis within its native plant community by consulting the available scientific literature. More work was dedicated to tracing the introduction history of the Malagasy smoke bush from its native range, especially to European countries, to Italy and Sicily. Time is a relevant component of invasive dynamics because time lags, from introduction to outbreak stage, can vary widely among alien species. The main floristic lists of the botanical and public gardens, as well as any international, national and local botanical and horticultural texts reporting Buddleja or Nicodemia madagascariensis as cultivated, acclimatized or naturalized have been taken into account. 
To fill the lack of information on the presence of any cultivated Malagasy smoke bush mother plant in the surroundings of the investigated population, a growth-ring analysis was carried out to assess the age of some individuals of $N$. madagascariensis and so reconstruct the population dynamics of the whole nucleus. For this purpose, the two largest mature plants and one with an average diameter were felled and cross sections were taken at a height of $5 \mathrm{~cm}$ above ground to maximize the number of available rings. The samples were carefully dried and polished with sandpaper (grade between 80 and 1000 grains) until the anatomical features related to ring boundaries were clearly identified. After sample preparation, the cross sections were examined under a stereomicroscope for tree-ring analysis. The age was determined for each plant by counting the total number of rings from bark to pith. For each disc, three radii were selected and visually cross-dated by matching the pattern of narrow and wide rings between two plants (Stokes and Smiley 1996).

To characterize the ecological conditions of the study site, the data provided by the Osservatorio delle Acque (2015) concerning the monthly average air temperature and the total rainfall amount from 1980 to 2014 of the nearest meteorological station located in the ancient astronomical observatory of Palermo were considered. Local climate is typically Mediterranean, with a dry season, which usually lasts from May to August, while precipitation is concentrated from September to April. In the considered time span mean annual temperature was $18.9^{\circ} \mathrm{C}$, whereas absolute maximum and minimum temperatures were $30.2^{\circ} \mathrm{C}$ and $8.7^{\circ} \mathrm{C}$, respectively. Annual mean rainfall was $552.4 \mathrm{~mm}$.

\section{Results and Discussion}

\section{From discovery to cultivation, from success to invasion}

This plant was first collected in Madagascar around 1770 by the French explorers and botanists Philibert Commerson and Pierre Sonnerat. Some exsiccata were sent to the Jardin du Roi (later named the Jardin des Plantes), from where it was published by Lamarck (1785) with the binomial epithet 'Budleia' madagascariensis. It was not however introduced to European gardens until much later, as testified by a French scientific dictionary of 1822, which states that it was not yet in cultivation (Luckhurst 2008). Sauvaigo (1899) generally reports 1824 as the year of its first introduction in Europe, while Staples \& Herbst (2005) state that it was introduced in Great Britain around 1825, when it was actually present in the Royal Botanic Garden of Glasgow (Hooker 1825). The first reliable information about its ability to produce flowers concerns a plant born from the seeds sent by Nathaniel Wallich, curator of the botanic garden of Calcutta, to Britain, which flowered in the autumn of 1827. The event was described and illustrated just 1 year later by Hooker (1828) in Curtis's Botanical Magazine with the epithet 'Buddlea' madagascariensis and by Lindley
(1829), who created the superfluous later synonym 'Buddlea' heterophylla. During the following decades it was introduced into cultivation in many other European botanical gardens (Leeuwenberg 1979). Since then, it has been introduced in almost all the tropical and subtropical regions of the world such as south Asia, North America, West Indies, South America, southern Europe, north and south Africa, Pacific Islands, west Australia and Micronesia (Binggeli 1998; Space and Falanruw 1999; Weber 2003; GISD 2010; Norman 2012).

Nowadays $N$. madagascariensis is almost completely naturalized in many tropical and subtropical areas such as west Australia, south Africa, south China, USA and Brazil (Leeuwenberg 1979; Li and Leeuwenberg 1996; Foxcroft 1999; Randall 2002; Wunderlin and Hansen 2002; Schneider 2007), and it has recently threatened with invasion the disturbed forest ecosystems of many oceanic islands (Wagner et al. 1999; The Environmental Conservation Section 1999; Liogier and Martorell 2000; PIER 2002; Kairo et al. 2003; Beauvais et al. 2005; Gray et al. 2005; Howell 2008).

\section{History of cultivation in Mediterranean area, Italy and Sicily}

Despite its ancient introduction in Mediterranean Europe, it has been only recently recorded as a casual alien along the coasts of southern Greece (Raus 2007) and Malta and Gozo (Mifsud 2008). Although Leeuwenberg (1979) observed some Cretan individuals of $N$. madagascariensis being able to make fruits, 35 years after it still occurs there only in cultivation (Dal Cin d'Agata et al. 2009). Also, its naturalization in southern France, reported by Stuart (2006), remains rather questionable: in fact, neither the updated 'Silene' database (http://flore.silene.eu/in dex.php?cont=accueil) nor the very recent floras concerning the whole country (Tison \& De Foucault 2014) and its Mediterranean sector (Tison et al. 2014) mention it. Similarly, it has not been possible to confirm its presence as escaped in Libya and Cyprus, as recently reported by Valdés (2012), and N. madagascariensis is not even mentioned within a recent inventory of casual, naturalized and invasive alien species in Europe, which conversely includes six species of Buddleja (DAISIE 2009).

The first record of its cultivation in Italy dates back to 1840 , when it was introduced in Naples botanical garden (Tenore 1840). In the following decade it was introduced also in Lombardy at Monza (Manetti 1842), Caserta (Terracciano 1869), Cagliari (Beccari 1869), Ferrara (Massalongo 1897), and in Hanbury Gardens in Liguria (Leeuwenberg 1979). Borzì (1894) was the first to testify the presence of $N$. madagascariensis in Sicily, while the date of introduction reported by Ostinelli (1910), i.e. 'Madagascar 1824', is unreliable as are those concerning the other buddlejas cultivated at Villa Trabia (where N. madagascariensis does not occur anymore; Dr Manlio Speciale, pers. comm.) at that time. For example, 
concerning the introduction of Buddleja colvilei Hook. f., Ostinelli (1910) indicates '1829 Himalaya', whereas the species was actually discovered only in 1849 by Joseph Dalton Hooker, who described it 6 years later (Hooker 1855). Furthermore, N. madagascariensis does not figure in any of the numerous plant catalogues of the botanical gardens of Palermo and Boccadifalco, which have been consulted (Gussone 1821, 1825, 1826; Tineo 1827; Gasparrini 1830; Todaro 1858, 1860, 1862, 1868, 1875, 1876, 1877; Borzì 1893).

The use of the plant for ornamental purposes probably spread throughout the private gardens of the island between the end of the nineteenth and beginning of the twentieth centuries: Leeuwenberg (1979) mentions a sample collected in flower at Taormina by Bornmüller, who visited the town during April-May 1933 (Domina et al. 2011). Indeed, the plant is still cultivated there in the 'Duca di Cesarò' city park (Bonasera et al. 2005) and at Giardino Colonna (Guglielmo et al. 2006a). On Pantelleria island, it has been introduced in a private garden near Bagno dell'Acqua (V.1997, S. Pasta, pers. obs.), where few individuals are acclimatized (Montoleone 2011-2014) but not naturalized (T. La Mantia, II.2015, pers. obs.), as reported by Domina and Mazzola (2008). Moreover, it is present in the public garden 'Ignazio Scaturro' of Sciacca (Bazan et al. 2005), in the private gardens of Catania (Scrimali 2011). In the suburban area of Trapani, a huge at least 30-year-old individual used to grow on the borders of a private property at Villa Rosina before its recent destruction (L. Scuderi, pers. comm.).

\section{Description of the detected population}

Nicodemia madagascariensis was found at the beginning of May 2014 growing wild along a hedgerow delimiting an abandoned citrus orchard (Figure 1). The population

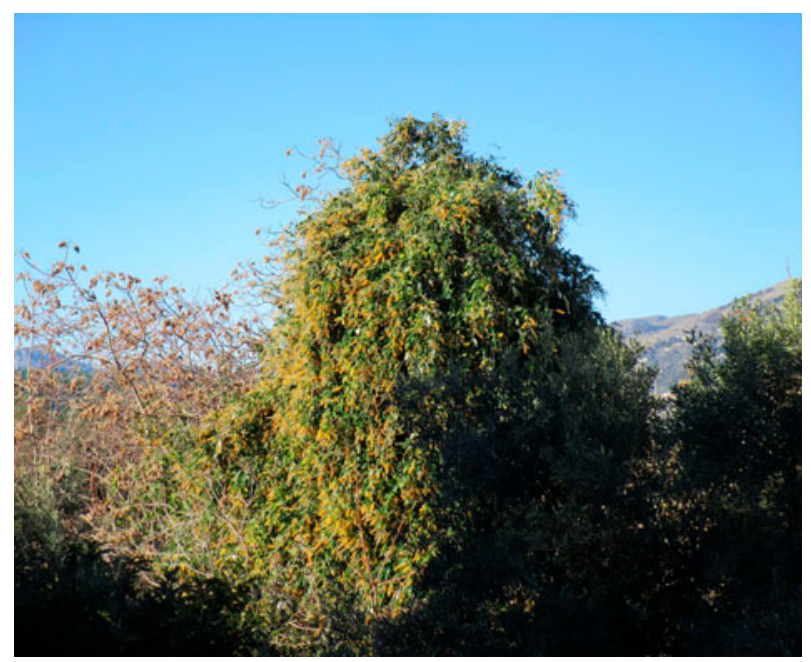

Figure 1. Nicodemia madagascariensis (centre of the picture) showing abundant flowering and smothering Ailanthus altissima, the species bearing brown fruits on the left. consisted of three different nuclei situated along the borders of the natural depression of the 'Fossa della Garofala' at 'Parco d'Orléans' public garden, about $15 \mathrm{~m}$ from each other (GPS coordinates: $38^{\circ} 06^{\prime} 25.19^{\prime \prime} \mathrm{N}$, $13^{\circ} 21^{\prime} 00.42^{\prime \prime}$ E, $43 \mathrm{~m}$ above sea level; the labels of three specimens, collected from the same plant, now deposited in Paris, Florence and Palermo Herbaria, bear the following basic information: 'E. Badalamenti, 19.II.2015, abandoned citrus orchards, southern escarpment of Fossa della Garofala').

The first nucleus is composed of 10 plants with an average diameter of $5.4 \mathrm{~cm}$ and with an average height of $6.1 \mathrm{~m}$; the second and third nuclei are each composed of seven plants with average diameters of 5.3 and 5.1 $\mathrm{cm}$ and average heights of 5.1 and $4.6 \mathrm{~m}$, respectively. In total there are 24 plants that reach a maximum height of almost $6.5 \mathrm{~m}$.

The Malagasy smoke bush is part of an alien-dominated plant community that has colonized an abandoned citrus orchard after the ceasing of local agricultural practices. Notwithstanding the fact that both the dominant trees, Ailanthus altissima (Mill.) Swingle (Figure 1) and Broussonetia papyrifera (L.) Vent., are able to perform a very fast vegetative spread, they seem not to have outcompeted Nicodemia, which instead grows over them, covers most of their crown and appears to be able to affect the light availability of the understorey.

Regarding the origin of the nuclei, many of the alien plants that have been planted in the last decades within Fossa della Garofala and that grow together with $N$. madagascariensis were collected by Prof. C. Laviola in Mozambique, where the Malagasy smoke bush is a common cultivated plant. Hence, the hypothesis that some seeds or some vegetative fragments of this plant could have been accidentally introduced in those circumstances cannot be discarded.

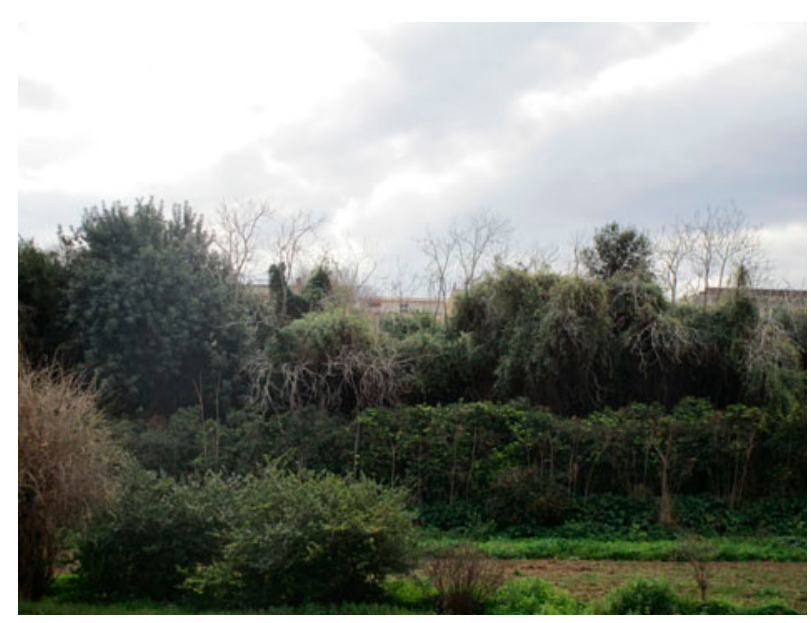

Figure 2. Linear distribution of Nicodemia madagascariensis. 


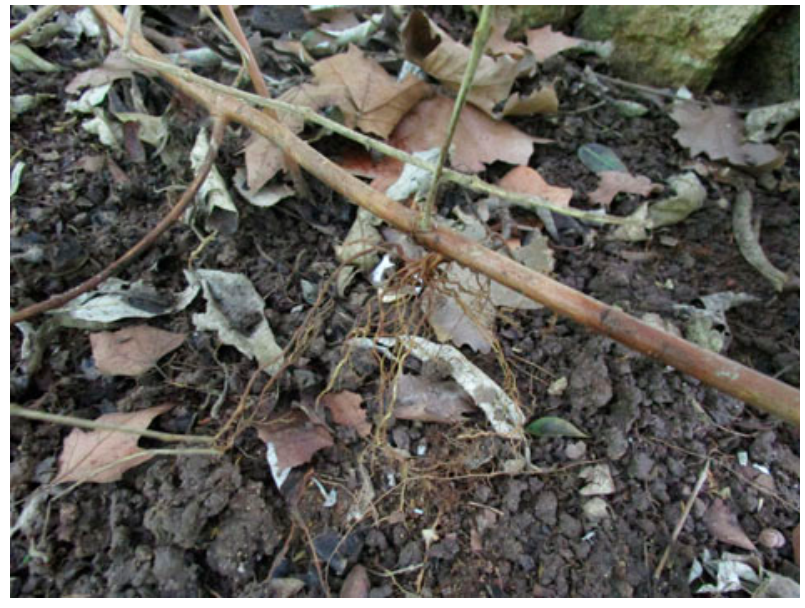

Figure 3. Adventive roots formed by the creeping stems reaching the ground.

Nowadays, the linear distribution pattern of the detected population (Figure 2) suggests that most of the plants issue from the vegetative spread of creeping stems (Figure 3). However, during our field observations we found that most of the plants produce seeds, but these are mostly not viable, as suggested by the lack of seedlings. Such behaviour is probably due to unfavourable environmental conditions, since the plant is known to set seeds in tropical and subtropical climate areas of the world (Weber 2003), whereas biotic factors allowing pollination and subsequent dissemination do not appear to be lacking in our study site.

On the other hand, the fresher and wetter conditions at the beginning of summer and/or the exceptionally mild autumns of the years 2011-2014 seem to have increased the endurance of the pollination of the Malagasy smoke bush by prolonging both its flowering period and the lifespan of its potential visitors (butterflies, bees, bumble bees and flies), captured by its attractive colours and its honey-like scent. During the first observation (2 May 2014), Nicodemia individuals were in full bloom (Figure 4). Later (21 December 2014), some bumble bees (Bombus terrestris L. 1758), together with other insects, such as Xylocopa violacea L. 1758 (violet

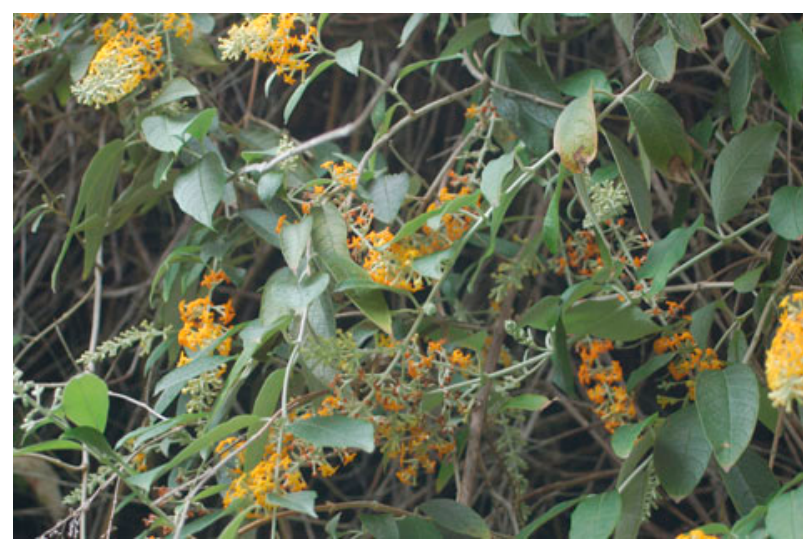

Figure 4. Detail of inflorescences. carpenter bee) and Macroglossum stellatarum L. 1758 (hummingbird hawk-moth), were observed visiting Nicodemia flowers at Fossa della Garofala. Bumble bees were also observed (11 February 2015) at Pantelleria, and Montoleone (2011-2014) took a picture of Tropinota squalida squalida (Scopoli 1783) (a hairy beetle) on the same plants. These observations confirm the long-lasting flowering period (at least 5 months from December to May) of the species under thermo-Mediterranean climatic conditions, as recorded also in Malta and Gozo by Mifsud (2008).

Once ripe, its fleshy berries are eaten and dispersed by a wide spectrum of animals: failing lemurs (Goodman et al. 2006), there are still plenty of birds, rodents and other small mammals that may disperse them (GISD 2010; Hawaii Early Detection Network 2010). In Madagascar the seeds of $N$. madagascariensis are also dispersed by Columbidae (Hawkins 2013), which are quite common in Palermo. Also Psittacula krameri Scopoli 1769 (rose-ringed parakeet) could play an important role (Hawkins 2013). Interestingly, the only other Malagasy smoke bushes observed within the urban area of Palermo are those cultivated within the Botanical Garden, some 4 $\mathrm{km}$ from the detected nucleus, where an increasing number of these frugivorous escaped parrots have been present for almost 30 years, just like at Parco d'Orléans. The black rat (Rattus rattus L., 1758), which is very common within Fossa della Garofala, has already been proved to disperse the seeds of Buddleja asiatica Lour. (Shiels 2011).

The seeds of $N$. madagascariensis can also be dispersed by wind (Walker et al. 2006), but in our case this eventuality can be excluded considering the total absence of mother plants in the nearby area. Within its secondary range the seeds may also be dispersed with mud adhering to vehicles or to shoes and boots, or through vegetative fragmentation.

In our study site, the total absence of seedlings and saplings notwithstanding the abundant flower production and the long-lasting flowering season, suggest that sexual reproduction is still a very rare event, although it seems to have occurred sometimes in the Botanical Garden of Palermo (Index Seminum 2009). However, N. madagascariensis is able to propagate via root suckers with annual shoots also exceeding $1 \mathrm{~m}$ in height.

In west Australia N. madagascariensis is still unable to produce fertile seeds (Stock and Wild 2002; Weed Society of Victoria 2008), but it has been found to be able to escape from gardens and to spread over considerable distances through vegetative mechanisms. Once displaced from gardens as hays or green wastes, their vegetative fragments can root elsewhere (Stock and Wild 2002).

Considering the wide spectrum of casual dispersers (including men) and its ability to overtop native species, smothering and eventually leading to their death (Starr et al. 2003), in west Australia it has been included among environmental weeds (Keighery and Longman 2004). 


\section{Growth-ring analysis}

One ray of the woody tissue of the two largest plants was completely decomposed forming large cavities. According to the InsideWood database (http://inside wood.lib.ncsu.edu/description?13) N. madagascariensis shows distinct growth-ring boundaries, and diffusive porosity without differences between latewood and earlywood was found by Aguilar-Rodríguez and Terrazas (2001). The investigated plants bore more discontinuous rings; besides, as the pith was not located in the centre and the annual growth-ring pattern was rather irregular, cross-dating was difficult. The estimated ages of the investigated plants were 18, 22 and 32 years, so the arrival of the species in the site of Fossa della Garofala dates back to the last 20 years of the twentieth century. The diameters of the samples were $6.5 \mathrm{~cm}, 7.5 \mathrm{~cm}$ and $9 \mathrm{~cm}$.

\section{Concluding remarks}

Urban areas may represent, in many cases, the main and the first pathway for the introduction of invasive alien species, and frequently they are the first environments where the tendency to become naturalized is observed (Celesti Grapow and Blasi 1998; Thompson and McCarthy 2008). This is mostly due to the large use of alien species for the decoration of streets, avenues and urban green areas, such as private and public gardens and parks, as well as botanical gardens. Moreover, frequently disturbed and nutrient-enriched urban and suburban sites are known to be particularly suitable for the establishment of alien plants (Mack et al. 2000). The city of Palermo, along with its surroundings, represents an emblematic target of alien woody plant invasion: in fact, a huge number of alien trees has been introduced during the last two centuries and more than 12,000 alien ornamental trees thrive there according to Pintagro (1999). Besides, a significant increase of naturalization events has recently occurred there, such as Ficus microcarpa L. and Cardiospermum grandiflorum Sw. (Schicchi 1999), Ficus watkinsiana F.M. Bailey (Schicchi and Mazzola 2003), Koelreuteria paniculata Laxm. and Washingtonia filifera (André) de Bary (Raimondo and Spadaro 2006), Solanum capsicastrum Schauer (Badalamenti et al. 2011), Schinus molle L. (Badalamenti et al. 2012b), Melia azedarach L. (Badalamenti et al. 2013) and Ceiba speciosa (A. St.-Hil.) Ravenna (Pasta et al. 2014). Most of the above-mentioned species are strictly confined to urban and suburban areas, where they colonize bare soils, street borders, abandoned railways, pavements and wall crevices or other artificial surfaces; however, some of them, in particular Ailanthus altissima (Badalamenti et al. 2012a), have proven to be able to spread from urban environments to semi-natural and natural areas, also including abandoned cultivated areas, where their ecological impact is expected to be far higher. As concerns the invasive potential of the Malagasy smoke bush, our investigations point out that it is a rare cultivated species on the island: in fact, it does not figure on the most relevant literature concerning both the private and the public green areas of the most populated Sicilian provinces, i.e. Palermo (Mazzola et al. 2006), Catania (Guglielmo et al. 2006b) and Messina (Salmeri et al. 2007; Giaimi 2009). Hence, its low frequency and abundance significantly reduce the likelihood of its escape from cultivation, at least up to now. On the other hand, considering that its congener Buddleja davidii Franch. has already shown a remarkable ability to colonize and invade all the temperate areas of the world (Randall 2012), special attention should be paid to the trend of the Malagasy smoke bush population along southern European coasts to avoid its sudden invasion of Mediterranean pre-forest and forest plant communities.

Our efforts to forecast the future behaviour of $N$. madagascariensis are biased by the common occurrence of rather long time lags between first establishment and the starting of invasive processes (Kowarik 1995; Crooks 2005) and because of impressive niche shifts experienced by many alien plants during establishment phase and in first steps of invasion (Thuiller et al. 2005; Pearman et al. 2008).

Moreover, ongoing climate warming may not only provide more suitable climatic conditions for tropical and sub-tropical species throughout the Mediterranean area, but may affect the interactions between alien plants, pollinators and seed dispersers, so changing ecosystem functioning.

Further investigations are needed on the reproductive (i.e. pollination and dispersal) strategies and partners (i.e. animals that act as pollinators and dispersers) of alien plants, which may play a key role by favouring their sudden spread.

Applying the EPPO (European and Mediterranean Plant Protection Organization) proritization process (Brunel et al. 2010), we suggest including N. madagascariensis in the 'observation list of invasive alien plants', for which a pest risk analysis is not required. In effect, information is still limited about its invasive behaviour; indeed, the level of overall uncertainty of the invasive assessment should be rated as 'high'. In more detail, in light of the available literature concerning the naturalization process of Nicodemia in the EPPO countries, we consider its potential for spread as 'medium' (A.5). Its spread is actually very scarce, especially due to its inability to produce fertile fruits; however, this chance may occur in the near future and ongoing climate change as well as diffusion through unintended transport of stem fragments (Stock and Wild 2002), may be a key driver for further spread. The potential negative impacts by Nicodemia on semi-natural and/or natural habitats (A.6) and on agriculture, horticulture and forestry (A.7) have also to be considered 'medium' because this alien species could be potentially dangerous but until now its distribution range is too narrow to determine effective impacts. It needs to be pointed out that in the area under assessment the alien species should be considered as 
locally invasive because of its prominent ability to overtop underlying species and to reach the dominant layer of the vegetation. No additional impacts are recorded (A.8).

\section{Acknowledgements}

This paper is dedicated to the memory of Berthe Franquet (married Rambaud, 31/05/1908-07/04/1986), the great-aunt of the first author, who spent five years (1939-1944) of her life in Antananarivo enjoying the overwhelming beauty of Madagascar's landscape and the sweetness of local people. We are also grateful to Dr Leonardo Scuderi for sharing with us some personal observations, to Ignazio Sparacio who identified Tropinota squalida squalida, and to Dr Jean-Marc Dufour-Dror (researcher and consultant in applied ecology, Jerusalem, Israel) for his helpful comments and suggestions, which improved the quality of the manuscript. We are grateful to Prof. Cesare Laviola for his personal communication on the introduction of plants from Mozambique, to Dr Manlio Speciale for providing some information on the past cultivation of N. madagascariensis in Sicily. The observations on the individuals of Pantelleria and the growth-ring analysis were carried out during the studies on secondary succession in the framework of the project ' $\mathrm{Cli}$ mate change mitigation strategies in tree crops and forestry in Italy (CARBOTREES)'.

\section{References}

Aguilar-Rodríguez S, Terrazas T. 2001. Anatomía de la madera de Buddleja L. (Buddlejaceae): análisis fenético. Mad y Bosq. 7:63-85.

Badalamenti E, Barone E, Pasta S, Sala G, La Mantia T. 2012a. Ailanthus altissima (Mill.) Swingle (fam. Simaroubaceae) in Sicilia e cenni storici sulla sua introduzione in Italia [Ailanthus altissima (Mill.) Swingle (Simaroubaceae) in Sicily and historical remarks on its introduction in Italy]. Naturalista Sicil. 36:117-164.

Badalamenti E, Cusimano D, La Mantia T, Pasta S. 2013. The recent spread of the invasive woody alien plant Melia azedarach L. (Meliaceae) in Sicily. Naturalista Sicil. 37:505513.

Badalamenti E, Pasta S, La Mantia T. 2011. Solanum capsicastrum Schauer (Solanaceae) spontaneizzato nella Piana di Palermo (Sicilia nord-occidentale) [Solanum capsicastrum Schauer (Solanaceae) naturalized in the Plain of Palermo (NW Sicily)]. Naturalista Sicil. 35:445-447.

Badalamenti E, Pasta S, La Mantia T. 2012b. Primi segnali di spontaneizzazione di Schinus molle L. (Anacardiaceae) in Sicilia [First evidences of naturalization of Schinus molle L. (Anacardiaceae) in Sicily]. Naturalista Sicil. 36:165-167.

Bazan G, Geraci A, Raimondo FM. 2005. La componente floristica dei giardini storici siciliani. Quad Bot Amb Appl. 16:93-126.

Beauvais M-L, Coléno A, Jourdan H, editors. 2005. Les espèces envahissantes dans l'archipel néo-calédonien. Un risque environnemental et économique majeur. Paris: Editions de l'Institut de Recherche pour le Développement.

Beccari O. 1869. 'Varietà e notizie' [Variety and news, without title]. Bull Soc Bot Ital. 159.

Binggeli P. 1998. An overview of invasive woody plants in the Tropics. Bangor: School of Agricultural and Forest Sciences Publication 13, University of Wales.

Bonasera G, Bazan G, Speciale M. 2005. Il Parco 'Duca di Cesarò’ di Taormina. Quad Bot Amb Appl. 16:279-288.
Borzì A. 1893. Delectus seminum e collectione anni 1894 Hortus Botanicus Regiae Universitatis Panormitanae pro mutua commutatione offert. Tip. Priulla, Palermo, $48 \mathrm{p}$.

Borzì A. 1894. Delectus seminum e collectione anni 1894 Hortus Botanicus Regiae Universitatis Panormitanae pro mutua commutatione offert. Tip. Priulla, Palermo, $40 \mathrm{p}$.

Brunel S, Branquart E, Fried G, Van Valkenburg J, Brundu G, Starfinger U, Buholzer S, Uludag A, Joseffson M, Baker R. 2010. The EPPO prioritization process for invasive alien plants. EPPO Bulletin 40(3):407-422.

Celesti Grapow L, Blasi C. 1998. A comparison of the urban flora of different phytoclimatic regions in Italy. Global Ecol Biogeogr Lett. 7:367-378.

Crooks JA. 2005. Lag times and exotic species: the ecology and management of biological invasions in slow-motion. Ecoscience. 12:316-329.

DAISIE. 2009. Handbook of alien species in Europe. Dordrecht: Springer, $428 \mathrm{p}$.

Dal Cin D'Agata C, Skoula M, Brundu G. 2009. A preliminary inventory of the alien flora of Crete (Greece). Bocconea. 23:301-315.

Domina G, Marino P, Castellano G. 2011. The genus Orobanche (Orobanchaceae) in Sicily. Flora Mediterranea. 21:205-242.

Domina G, Mazzola P. 2008. Flora ornamentale delle isole circumsiciliane. Quad Bot Amb Appl. 19:107-119.

Foxcroft L. 1999. The control of alien plants within personnel villages, other staff residences, and rest camps of the Kruger National Park. Scientific Services, Alien Biota, Kruger National Park, South Africa [cited 2014 Dec 7]. Available from: http://www.parkssa.co.az/conservation/scientific_ser vices/Biota/villageplantpolicy.html.

Gasparrini G. 1830. Index seminum anni 1830 quae ab horto regio in Boccadifalco prope Panormun pro mutua commutatione exhibentur. Palermo, $7 \mathrm{p}$.

Giaimi A. 2009. Censimento del verde pubblico nella città di Messina. Quad Bot Amb Appl. 20:269-274.

Global Invasive Species Database (GISD) [Internet]. 2010. Buddleja madagascariensis. NBII (National Biological Information Infrastructure) \& IUCN/SSC Invasive Species Specialist Group (ISSG), [cited 2014 Dec 7]. Available from: http://www.issg.org/database/species/ecology.asp?si= $1577 \& \mathrm{fr}=1 \&$ sts $=\&$ lang $=\mathrm{EN}$.

Goodman SM, Rakotoarisoa SV, Wilmé L. 2006. The distribution and biogeography of the Ringtailed Lemur (Lemur catta) in Madagascar. Chapter 1. In: Jolly A, Sussman RW, Koyama N, Rasamimanana $\mathrm{H}$, editors. Ringtail lemur biology: Lemur catta in Madagascar. Philadelphia: Springer, p. 3-15.

Gray A, Pelembe T, Stroud S. 2005. The conservation of the endemic vascular flora of Ascension Island and threats from alien species. Oryx. 39:449-453.

Guglielmo A, Pavone P, Salmeri C. 2006a. Giardini del XVIII secolo nel centro storico di Catania (Sicilia orientale). Quad Bot Amb Appl. 17:141-150.

Guglielmo A, Pavone P, Salmeri C. 2006b. Su alcuni giardini storici della Sicilia orientale, in C.RI.Be.Cu.M (a cura di), "L'approccio multidisciplinare allo studio ed alla valorizzazione dei beni culturali" (Siracusa, 28-29 ottobre 2005), Università degli Studi di Catania, Centro di Ricerca C.RI.Be.Cu.M., Aracne Editrice s.r.l., Roma, p. 229-244.

Gussone G. 1821. Catalogus plantarum Quae asservantur in Regio Horto serenissimi Francisci Borbonii Principis Juventutis, in Boccadifalco, prope Panormum.Typis Angeli Trani, Neapoli, 84 p.

Gussone G. 1825. Index seminum anni 1825 quae ab horto regio in Boccadifalco pro mutua commutatione exhibentur. Palermo, 12 p. 
Gussone G. 1826. Index seminum anni 1826 quae ab horto regio in Boccadifalco prope Panormun pro mutua commutatione exhibentur. Ex Typographia Zambraja, Palermo, $10 \mathrm{p}$.

Hawaii Early Detection Network. 2010 [Internet]. [cited 2015 feb 1]. Available from: http://www.reportapest.org/pestlist/ budmad.htm.

Hawkins F. 2013. The Birds of Africa: Volume VIII: The Malagasy Region: Madagascar, Seychelles, Comoros, Mascarenes. A. \& C. Black, 1024 p.

Hooker JD. 1855. Buddleja colvilei, in: Hooker JD, Fitch WH, editors. Illustrations of Himalayan plants, Table 18.

Hooker WJ. 1825. A catalogue of plants contained in the Royal Botanic Garden of Glasgow in the year 1825. Andrew \& John M. Duncan, printers to the University, $68 \mathrm{p}$.

Hooker WJ. 1828. Buddlea madagascariensis Lam. Curtis's Botanical Magazine s. 2, II (LV), Table 2824.

Howell C. 2008. Consolidated list of environmental weeds in New Zealand. DOC Research and Development Series nr 292, Science and Technical Publishing, Department of Conservation, Wellington, NZ, 42 p. [cited 2014 Dec 7]. Available from: http://www.doc.govt.nz/upload/documents/ science-and-technical/drds292.pdf.

Index Seminum. 2009. Sporae et Semina Anni MMIX quae Hortus Botanicus Panormitanus pro mutua commutatione offert. Regione Sicilia, Assessorato Regionale Agricoltura e Foreste, $70 \mathrm{p}$.

InsideWood 2004-onwards. [Internet]. [cited 2014 Dec 7]. Available from http://insidewood.lib.ncsu.edu/search.

Kairo M, Ali B, Cheesman O, Haysom K, Murphy S. 2003. Invasive species threats in the Caribbean Region. Report in the Nature Conservancy, $134 \mathrm{p}$.

Keighery G, Longman V. 2004. The naturalized vascular plants of Western Australia 1: Checklist, environmental weeds and Distribution in IBRA Regions. Plant Protection Quarterly. 19:12-32.

Kowarik I. 1995. Time lags in biological invasions with regard to the success and failure of alien species. In: Pyšek $P$, Prach K, Reimánek M, Wade M, editors. Plant invasions: General aspects and special problems. Amsterdam: SPB Academic Publishing, p. 15-38.

Lamarck J-B. (de) 1785. Budleia madagascariensis, in Encyclopédie Methodique, Botanique, Tome $1^{\mathrm{er}}$. Paris chez librairie Panckoucke, Liège chez Plomteux: 513.

Leeuwenberg AJM. 1979. The Loganiaceae of Africa XVIII. Buddleja L. II, Revision of the African \& Asiatic species. Meded. Landbouwhogeschool Wageningen. 79:1-163.

Leeuwenberg AJM. 2005. Flore des Mascareignes. 123. Loganiacées, in: Bosser J, Guého J, editors. Flore des Mascareignes, Ed IRD, 140 p.

Li PT, Leeuwenberg AJM. 1996. Loganiaceae. In: Wu Z, Raven P, editors. Flora of China, Vol. 15. Beijing: Science Press, and St Louis, MO: Missouri Botanical Garden Press.

Lindley J. 1829. Buddlea heterophylla. Edward's botanical registrer or, ornamental flower-garden and shrubbery. Vol. XV, Table 1259. London: James Ridgway.

Liogier AH, Martorell LF. 2000. Flora of Puerto Rico and adjacent islands: a systematic synopsis. San Juan, Puerto Rico: La Editorial, UPR.

Luckhurst G. 2008. Buddleja madagascariensis. [cited 2014 Dec 7]. Available from: http://jardimformoso.blogspot.it/ 2008/12/buddleja-madagascariensis.html

Mack R, Simberloff D, Lonsdale W, Evans H, Clout M, Bazzaz F. 2000. Biotic invasions: causes, epidemiology, global consequences and control. Ecol Appl. 10:689-710.

Manetti G. 1842. Catalogus plantarum Caesarei Regii Horti prope Modiciam ad annum 1842. Imperialibus Regiis Typis, Milano, $107 \mathrm{p}$.

Massalongo C. 1897. Delectus seminum quae hortus botanicus universitatis ferrariensis pro mutua commutatione offert, anno 1897. Typ. Taddei rem proprie gerente A, Soati, Ferrariae, $40 \mathrm{p}$.

Mazzola P, Domina G, Mineo C, Alliata N. 2006. Il Parco di Villa Belmonte all'Acquasanta. Analisi del patrimonio floristico e ipotesi di restauro. Quad Bot Amb Appl. 17:89 [cited 2014 Dec 7].101.

Mifsud S. 2008. Buddleja madagascariensis. [cited 2014 Dec 7]. Available from: http://www.maltawildplants.com/SCRO/ Buddleja_madagascariensis.php.

Montoleone E. 2011-2014. - Buddleja madagascariensis Lam. Acta Plantarum, Forum. [cited 2014 Dec 7]. Available from: http://www.actaplantarum.org/floraitaliae/view topic.php? $\mathrm{f}=41 \& \mathrm{t}=58066$.

Norman EM. 2012. Buddleja Linnaeus. In Freeman CC, Rabeler RK, editors. Scrophulariaceae. Flora of North America, Provisional Publication. Flora of North America Association. [cited 2014 Dec 7]. Available from: fna.huh.harvard. edu/files/Scrophulariaceae.pdf.

Osservatorio delle acque. 2015. Thermo-pluviometric data: monthly temperature and rainfall. [cited 2015 Jan 31]. Available from: http://www.osservatorioacque.it/?cmd=page\& id=dati_annali_cons\&tpl=default.

Ostinelli V. 1910. Villa Trabia alle Terre Rosse. Tipografia Priulla, Palermo, $251 \mathrm{p}$

Pacific Islands Ecosystems at Risk (PIER) [Internet]. 2002. Invasive Plant Species: Buddleja madagascariensis. [cited 2014 Dec 7]. Available from: http://www.hear.org/pier.

Pareliussen I. 2004. Natural and experimental tree establishment in a fragmented forest, Ambohitantely Forest Reserve, Madagascar [Dr. Sci. Thesis]. Department of Biology, Faculty of Natural Sciences and Technology, Norwegian University of Science and Technology, $131 \mathrm{p}$.

Pasta S, La Mantia T, Badalamenti E. 2014. A casual alien new to Mediterranean Europe: Ceiba speciosa (A. St.-Hil.) Ravenna (Malvaceae) in the suburban area of Palermo (NW Sicily, Italy). Anales J Bot Madrid. 71:e010.

Pearman PB, Guisan A, Broennimann O, Randin CF. 2008. Niche dynamics in space and time. Trends Ecol Evol. 23:149-158

Pintagro M. 1999. Arborea. La storia di Palermo in cento alberi illustri. Palermo: Helix Media Editore.

Raimondo FM, Spadaro V. 2006. Casi di spontaneizzazione in Sicilia di specie esotiche ornamentali. Naturalista Sicil. 30:597-599.

Rakotondrasoa OL, Malaisse F, Rajoelison GL, Razafimanantoa TM, Rabearisoa MR, Ramamonnjisoa BS, Raminosoa N, Verheggen FJ, Poncelet M, Haubruge É, Bogaert J. 2012 La forêt de tapia, écosystème endémique de Madagascar: écologie, fonctions, causes de dégradation et de transformation (synthèse bibliographique). Biotech Agr Société Environ. 16:541-552.

Randall RP. 2002. Western Weeds, A-Z. Plant Protection Society of Western Australia. [cited 2014 Dec 7]. Available from: http://www.members.iinet.au/ weeds/western_weeds/ bud_cac caes.htm.

Randall RP. 2012. A Global Compendium of Weeds. 2nd Edition. Department of Agriculture and Food, Western Australia. [cited 2014 Dec 7]. Available from: http://archive. agric.wa.gov.au/objtwr/imported assets/content/pw/weed/glo bal-compendium-weeds.pdf.

Raus T. 2007. Buddleja madagascariensis Lam. In: Greuter W, Raus T, editors. Med-Checklist Notulae, 26. Willdenowia. $37: 435-444$.

Robisoa MA. 2010. Etude des successions végétales des forêts brulées du Tampoketsa d'Ankazobe pour la restauration de la forêt d'Ankafobe. Mémoire Diplôme d'Etudes Approfondies en Foresterie-Environnement et Développement, Ecole Supérieure des Sciences Agronomiques, Département des Eaux et Forêts, Université d'Antananarivo, xiv $+78+$ xxiv $p$. 
Salmeri C, Guglielmo A, Pavone P. 2007. Il Giardino di Villa "La Falconara" a Taormina (Sicilia orientale). Quad Bot Amb Appl. 18:93-98.

Sauvaigo E. 1899. Flora mediterranea exotica. Énumération des plantes cultivées dans les jardins de la Provence et de la Ligurie, avec un tableau des collections botaniques les plus importantes de Marseille à Gênes. Paris: Typographie J. Ventre, $454 \mathrm{p}$.

Schicchi R. 1999. Spontaneizzazione di Ficus microcarpa L. (Moraceae) e Cardiospermum grandiflorum Sw. (Sapindaceae) in Sicilia. Naturalista Sicil. 23:315-317.

Schicchi R, Mazzola P. 2003. Ficus watkinsiana F. M. Bailey, nuova xenofita siciliana. Naturalista Sicil. 27:307-311.

Schneider AA. 2007. The naturalized flora of Rio Grande do Sul State, Brazil; subspontaneous herbaceous plants. Biociências. 15:257-268.

Scrimali M. 2011. Buddleja madagascariensis [Internet]. Available from: http://www.verdeinsiemeweb.com/2012/01/bud dleja-madagascariensis.html (cited 2014 Dec 7).

Shiels AB. 2011. Frugivory by introduced black rats (Rattus rattus) promotes dispersal of invasive plant seeds. Biol Invasions. 13:781-792.

Space JC, Falanruw M. 1999. Observation on invasive plant species in Micronesia. Reports of the Meeting of the Pacific Islands Committee, Council of Western State Foresters, Majuro, Republic of the Marshall Islands (February 22-26, 1999), $32 \mathrm{p}$.

Staples GW, Herbst DR. 2005. A Tropical Garden Flora - Cultivated Plants in the Hawaiian Islands and Other Tropical areas. Honolulu, HI: Bishop Museum Press, 908 p.

Starr F, Starr K, Loope LL. 2003. Buddleia madagascariensis - Smoke bush - Buddlejaceae. USGS - Biological Resources Haleakala Field Station Maui [cited 2014 Dec 7]. Available from: http://www.hear.org/starr/hiplants/re ports/pdf/buddleia madagascariensis.pdf.

Stock DH, Wild CH. 2002. Natural propagation of orange buddleia (Buddleja madagascariensis Lamarck) in eastern Australia. In: Spafford Jacob H, Dodd J, Moore JH, editors. Papers and Proceedings of the $13^{\text {th }}$ Australian Weeds Conference, Newslett. Pl. Protect. Soc. W Australia, Perth, p. $120-123$.

Stokes MA, Smiley TL. 1996. An introduction to tree-ring dating. Tucson, AZ: University of Arizona Press, 73 p.

Stuart DD. 2006. Buddlejas. RHS Plant Collector Guide. Oregon: Timber Press.

Tenore M. 1840. Index seminum in Horto botanico neapolitano 1840 collectorum. Neapoli, 9 p.

Terracciano N. 1869. L'invernata del 1869 ed i suoi effetti sulla vegetazione. Nuovo Giorn Bot Ital. 1:244-246.

The Environmental Conservation Section 1999. The Flora of St. Helena Island. The Environmental Conservation Section, Agriculture and Forestry Department, Scotland, St. Helena, South Atlantic Ocean. [cited 2014 Dec 7].
Available from: http://www.home.swipnet.se/ $\sim$ w 17282/en demic/flora.html.

Thompson K, McCarthy MA. 2008. Traits of British alien and native urban plants. J Ecol. 96:853-859.

Thuiller W, Richardson DM, Pyšek P, Midgley GF, Hughes GO, Rouget M. 2005. Niche-based modelling as a tool for predicting the risk of alien plant invasions at a global scale. Glob Change Biol. 11:2234-2250.

Tineo V. 1827. Catalogus Plantarum Horti Regii Panormitani ad annum 1827. Palermo: Regale Tipografia, $284 \mathrm{p}$.

Tison J-M, De Foucault B, editors. 2014. Flora Gallica: Flore complète de la France. Editions Biotope, Mèze, 1400 p.

Tison J-M, Jauzein P, Michaud H. 2014. Flore de la France méditerranéenne continentale. Naturalia Publications, Turriers, $2080 \mathrm{p}$.

Todaro A. 1858. Index seminum Horti Regii Botanici Panormitani quae pro mutua commutatione offeruntur. Palermo, $46 \mathrm{p}$.

Todaro A. 1860. Index seminum Horti Regii Botanici Panormitani quae pro mutua commutatione offeruntur. Palermo, $28 \mathrm{p}$.

Todaro A. 1862. Index seminum Horti Regii Botanici Panormitani quae pro mutua commutatione offeruntur. Palermo, $35 \mathrm{p}$.

Todaro A. 1868. Index seminum Horti Regii Botanici Panormitani quae pro mutua commutatione offeruntur. Palermo, $36 \mathrm{p}$.

Todaro A. 1875. Index seminum Horti Regii Botanici Panormitani quae pro mutua commutatione offeruntur. Palermo, $44 \mathrm{p}$.

Todaro A. 1876. Index seminum Horti Regii Botanici Panormitani quae pro mutua commutatione offeruntur. Palermo, $46 \mathrm{p}$.

Todaro A. 1877. Index seminum Horti Regii Botanici Panormitani quae pro mutua commutatione offeruntur. Palermo, $38 \mathrm{p}$.

Valdés B. 2012. Buddlejaceae, in Euro+Med Plantbase, the information resource for Euro-Mediterranean plant diversity [Internet]. [cited 2014 Dec 7]. Available from: http://ww2. bgbm.org/euroPlusMed/PTaxonDetail.asp?UUID=79B038 EF-9F7A-41CA-B7A3-06B691886282.

Wagner WL, Herbst DR, Sohmer SH. 1999. Manual of the Flowering Plants of Hawai'i. 2 vols. Bishop Museum Special Publication 83. Honolulu: University of Hawai'i and Bishop Museum Press.

Walker LR, Bellingham PJ, Peltzer DA. 2006. Plant characteristics are poor predictors of microsite colonization during the first two years of primary succession. J Veg Sci. 17:397-406.

Weber E. 2003. Invasive Plant Species of the World. A Reference Guide to Environmental Weeds. Wallingford: CABI Publishing.

Weed Society of Victoria. 2008. Victorian Alert Weed: Smoke bush (Buddleja madagascariensis). Weedscene. 19:7. [cited 2014 Dec 7]. http://www.wsvic.org.au/files/weedscene/ Weedscene\%2019-3.pdf.

Wunderlin R, Hansen B. 2002. Atlas of Florida Vascular Plants. Institute for Systematic Botany, University of South Florida, Tampa, FL. [cited 2014 Dec 7]. Available from http://www.plantatlas.usf.edu/. 